IEA SHC Task 49

SolarPACES Annex IV

Solar Process Heat for Production and Advanced Applications

Catalogue of recommended components for advanced integration

Version 1.0, February, 2016

Author: Bettina Muster

with contribution from: Bastian Schmitt, llyes Ben Hassine 


\title{
IEA Solar Heating and Cooling Programme
}

The Solar Heating and Cooling Technology Collaboration Programme was founded in 1977 as one of the first multilateral technology initiatives ("Implementing Agreements") of the International Energy Agency. Its mission is "to enhance collective knowledge and application of solar heating and cooling through international collaboration to reach the goal set in the vision of solar thermal energy meeting 50\% of low temperature heating and cooling demand by 2050.

The members of the IEA SHC collaborate on projects (referred to as "Tasks") in the field of research, development, demonstration (RD\&D), and test methods for solar thermal energy and solar buildings.

A total of 57 such projects have been initiated, 47 of which have been completed. Research topics include:

A Solar Space Heating and Water Heating (Tasks 14, 19, 26, 44, 54)

A Solar Cooling (Tasks 25, 38, 48, 53)

A Solar Heat or Industrial or Agricultural Processes (Tasks 29, 33, 49)

A Solar District Heating (Tasks 7, 45, 55)

A Solar Buildings/Architecture/Urban Planning (Tasks 8, 11, 12, 13, 20, 22, 23, 28, 37, 40, $41,47,51,52,56)$

A Solar Thermal \& PV (Tasks 16,35$)$

A Daylighting/Lighting (Tasks 21, 31, 50)

A. Materials/Components for Solar Heating and Cooling (Tasks 2, 3, 6, 10, 18, 27, 39)

A Standards, Certification, and Test Methods (Tasks 14, 24, 34, 43, 57)

A Resource Assessment (Tasks 1, 4, 5, 9, 17, 36, 46)

A Storage of Solar Heat (Tasks 7, 32, 42)

In addition to the project work, there are special activities:

$>$ SHC International Conference on Solar Heating and Cooling for Buildings and Industry

$>$ Solar Heat Worldwide - annual statistics publication

> Memorandum of Understanding - working agreement with solar thermal trade organizations

> Workshops and seminars

\section{Country Members}

Australia

Austria

Belgium

Canada

China

Denmark

European Commission

France
Germany
Italy
Mexico
Netherlands
Norway
Singapore

Slovakia

Spain

South Africa

Sweden

Switzerland

Turkey

Portugal

United Kingdom

\author{
Sponsor Members \\ European Copper Institute (ECl) \\ ECREEE \\ Gulf Organization for Research and Development (GORD) \\ International Solar Energy Society \\ RCREEE
}

For more information on the IEA SHC work, including many free publications, please visit www.iea-shc.org 


\section{Catalogue of recommended components for advanced integration}

In this catalogue, software and hardware components are described that can help realising the integration of solar process heat in an advanced way. The list gives an overview on all important aspects and therefore embraces topics from all subtasks. For each of the software/hardware components more information can be found in specific result documents from IEA Task 49.

Although the primary intention was to focus on additional required components for integrating solar heat with new emerging process technologies, this report understands "advanced integration" as an intelligent integration concept by any means: sensibly placed in the industrial environment, realised with best suited system concepts, featuring new stagnation concepts, and well monitored with suitable performance assessment figures. "Advanced integration" can in this sense tackle integration points with existing process equipment or link solar process heat to emerging process technologies. The integration effort might differ based on the process equipment in use, but there will be no additional required components for "new/emerging" process technologies specifically. With optimized process equipment it will rather be the aim in future to simplify integration due to better heat transfer or less heat exchange area required.

\begin{tabular}{|c|c|}
\hline Software components/Information Sources: & $\begin{array}{l}\text { Links to specific document from } \\
\text { Task } 49\end{array}$ \\
\hline $\begin{array}{l}\text { Modelling tools to assess potential of emerging } \\
\text { process technologies }\end{array}$ & \\
\hline $\begin{array}{l}\text { Advanced heat integration tools / Simulation tools } \\
\text { for holistic heat flow analysis }\end{array}$ & Krummenacher and Muster, 2015, B1 \\
\hline Use of applicable integration concept & $\begin{array}{l}\text { Schmitt in Muster et al, 2015, B2 } \\
\text { Integration Guideline }\end{array}$ \\
\hline Heat exchanger design tools & Krummenacher and Muster, 2015, B1 \\
\hline Use of applicable SHIP system concept & $\begin{array}{l}\text { Helmke and Hess in Muster et al, 2015, } \\
\text { B2 Integration Guideline }\end{array}$ \\
\hline $\begin{array}{l}\text { Solar simulation tools / Simulation tools for } \\
\text { holistic heat flow analysis }\end{array}$ & $\begin{array}{l}\text { Platzer et al., 2015, C2 Simulation Tool } \\
\text { Overview } \\
\text { Design tool, InSun Project } \\
\text { http://www.fp7-insun.eu/DesignTool/ } \\
\text { GainBuddy, SPF } \\
\text { http://www.spf.ch/GainBuddy.297.0.html }\end{array}$ \\
\hline Hydraulic planning tools & $\begin{array}{l}\text { TubeCalc, SPF } \\
\text { http://www.spf.ch/TubeCalc.65.0.html } \\
\text { manufacturer specific software like: } \\
\text { SAMSON valve designer } \\
\text { Mauthner et al., Development of a } \\
\text { design tool for the optimization of the } \\
\text { collector hydraulics of large-scale solar } \\
\text { thermal systems, Deliverable within } \\
\text { Solabrew project }\end{array}$ \\
\hline $\begin{array}{l}\text { Performance assessment tools based on } \\
\text { monitoring data }\end{array}$ & $\begin{array}{lcr}\text { Platzer, } 2015, \quad \text { C3 } & \text { Performance } \\
\text { Assessment Methodology } & \end{array}$ \\
\hline
\end{tabular}




\begin{tabular}{|c|c|}
\hline Hardware components & $\begin{array}{l}\text { Links to specific document from } \\
\text { Task } 49\end{array}$ \\
\hline Suitable collector technology & $\begin{array}{l}\text { Frank, 2013, A1 Process Heat } \\
\text { Collectors - Definition } \\
\text { Horta, 2016, A2 Overview of State of } \\
\text { the Art of Process Heat Collectors }\end{array}$ \\
\hline Suitable storage technology & $\begin{array}{l}\text { Helmke and Hess in Muster et al, 2015, } \\
\text { B2 Integration Guideline } \\
\text { Platzer et al., 2016, C1 Design } \\
\text { Guidelines }\end{array}$ \\
\hline \multicolumn{2}{|l|}{ state-of-the-art hydraulic components } \\
\hline \multicolumn{2}{|l|}{ Heat exchangers } \\
\hline \multicolumn{2}{|l|}{ Pipings and insulation } \\
\hline Advanced control systems & I/O controller ISFH \\
\hline Suitable stagnation prevention & Frank et al., 2014, A2 Stagnation \\
\hline $\begin{array}{l}\text { measurement equipment for collector field } \\
\text { efficiency and integration efficiency }\end{array}$ & $\begin{array}{ll}\text { Platzer, 2015, C3 Performance } \\
\text { Assessment Methodology }\end{array}$ \\
\hline
\end{tabular}

